\title{
Does Writing Have Any Effect on Mathematics Success?
}

\author{
Sefa Dündar \\ Correspondence: Sefa Dündar, Department of Primary Mathematics Education, Faculty of Education, Abant Izzet \\ Baysal University, Bolu, Turkey
}

Received: July 30, 2015 Accepted: August 18, $2015 \quad$ Online Published: September 18, 2015

doi:10.11114/jets.v4i1.989

URL: http://dx.doi.org/10.11114/jets.v4i1.989

\begin{abstract}
In this study, the relationship between mathematics success and the formal properties and contents of the notebooks in which students take notes during mathematics classes have been examined. The exploratory model, in which quantitative and qualitative data are used together, has been used in this study. This study consists of 176 students from 3 different state secondary schools and the notebooks they used to take notes in during math classes, as well as their academic success assessments. It has been found that the properties from the contents of the notebooks of successful students are more remarkable than those who are unsuccessful, and the formal properties of the notebooks are not different from each other according to success rates. With this study, it has become obvious that note-taking in math classes is important in terms of the form and the process. Moreover, it has been concluded that there is no meaningful relationship between the contents and the formal properties of the notebooks. Therefore, it is believed that organizing seminars for students on better note-taking methods at the beginning of the semester will increase mathematical success.
\end{abstract}

Keywords: writing in math, mathematics success, teaching mathematics, writing format

\section{Introduction}

In daily life, the need for understanding and using mathematics has gained increasing importance. Therefore, those students who succeed in math have more options in terms of forming their futures. These issues should be considered during the design stage of math programs. Together with developing mathematical concepts, some important skills can also be developed, such as problem solving, establishing communication, reasoning, and making interconnections (Ministry of National Education [MoNE], 2009).

The skills that are developed in math programs have different levels of importance within themselves. One of these important skills is the ability to establish communication. Math programs encourage students to establish communication using mathematical knowledge. One of skill is the action of writing. According to Atasoy (2005), mathematical communication increased in the classroom by writing, which also helps students from positive attitudes towards mathematics and writing in general. Writing is one of the actions related to self-organizing skills (Albert, 2000; Graham \& Harris, 2000), which is fundamental in mathematics education. Note-taking is one of the most common study activities in school settings (Lahtinen, Lonka, \& Lindblom-Ylanne, 1997). Writing is also one of the fundamental means of communication between teachers and students in mathematics education. Since writing has an important role in mathematics education, mathematics should be part of the curriculum (NCTM, 1989). According to Countryman (1992), mathematics is one of the ways to understand the world, and writing is one of the ways to understand mathematics. Writing enables a higher rate of retention in our memories and helps us to understand mathematical concepts, and even enhances learning in certain conditions (Kobayashi, 2005). It is important to ensure that students express themselves with the notes they take during classes and activities, since writing is also a key way to share mathematical ideas with others.

It is believed that writing activities in mathematics will help students in many areas, including awareness, making connections with previously-learned information, arousing curiosity, strengthening reading and communication skills, encouraging analysis and synthesis, expressing attitudes and emotions, teacher-student interaction, structuralizing motivation information, and organizing and sustaining thoughts (MoNE, 2012; O'Connell, 2007; Rothstein, Rothstein, \& Lauber, 2007; Song, 1997).

An individual reorganizes the information in his/her brain by reviewing, questioning, making interconnections, and controlling the data, etc. (Freitag, 2004; Güneş, 2013). For example, a teacher can examine the notes of a student who is engaged in problem solving activities to help better explain the problem solving methodology and the meaning of a rule 
(Yore, Pimm \& Tuan, 2007). As a result, it has become obvious that examining the problem solving process reveals clues about the cognitive process of students' notes, how they learn, and how they understand their thoughts (Pugalee, 2001). Therefore, writing activities are one of the measures that are most commonly referred to in examining the mathematical problem solving processes of students (Taylor \& McDonald, 2007; Browne, 1999). Furthermore, writing and note-taking will help students to gain a better understanding of the concepts. However, it is believed that writing should not be thought of as an activity, but as a process (Çakmak, 2013). The reason is that this process requires some cognitive items, such as psychological and ideological items, as well as planning, decision-making, and making interconnections. Moreover, during writing activities, thoughts are reorganized in terms of making limitations and classifications, and putting them in order (MoNE, 2012). Therefore, this situation is observed to be directly related to a student's success in the classroom, and to making individual differences visible.

It is believed by many researchers that writing activities are the best means of effective communication between students and teachers. It has been observed that students undergo a certain process during the writing activities, and that teachers have some important duties in this process as well. Some of these duties include encouraging students to write, helping them to develop positive attitudes toward writing, helping those students who have writing difficulties to start and sustain writing, and helping students to develop cognitive skills through writing. It is believed that integrating writing activities with mathematics can be very useful for students, because having students with good mathematical communication will be helpful for their teachers and this will give those students an opportunity to classify their thoughts on mathematics. Writing activities particularly contribute to the cognitive levels of students who are at or around medium level (school average), provides teachers with an immediate source of rich and valuable information about what happens in the classroom, and helps to bring about changes in teaching activities and thus affect teachers' professional development in a positive way (Atasoy, 2012). According to Burns (2004), the writing assignments fall into four categories: keeping journals or logs, solving math problems, explaining mathematical ideas, and writing about learning processes.

In the literature, there is an emphasis on different aspects of writing. Writing is defined in different ways (Demircioğlu, Argün, \& Bulut, 2010), such as a means of learning (Jurdak \& Zein, 1998), a learning activity (Shield \& Galbraith, 1998), and a learning strategy (Phillips and Crespo, 1996). In a study by Rice (2004), it was suggested that there was a positive relationship between writing and understanding mathematics and that writing activities should be used to teach mathematics to students. In another study by Frenkel (2004), it was suggested that writing activities not only support better understanding of mathematics but also help to explore the effects of using writing techniques. It also became clear that it helped students to solve problems and analyze thoughts. Moreover, writing activities in mathematics are an excellent way to engage students' thinking processes and discover the hidden realities beyond the classroom environment (Connelly, 2005). Drew (2003) states in his study that the practice of writing changes the opinions of students regarding mathematics and increases their knowledge. According to Pugalee (2004), students who are able to express their ideas through writing are more successful problem solvers than students who express their ideas verbally. Moreover, Powell (1997) states that it is easier to examine mathematical ideas and give feedback to students through the act of writing. Therefore, in this study, the mathematics grades of students are correlated with their mathematics success due to the fact that the act of writing has played an important role in examining ideas.

Regarding the curriculum of teaching writing in the MoNE (MoNE, 2012), it is stated that the formal and contextual complements in writing should be taken into consideration. Therefore, the aim of this study is to examine the effects of the notebooks in which students took notes in math classes in relation to mathematic success in terms of formal and contextual properties. For this purpose, the following research questions have been asked:

1- Is there a meaningful relationship between the formal state points according to the "Notebook Point Key" of the students' notebooks and their success in mathematics?

2- Is there a meaningful relationship between the contextual state points according to the "Notebook Point Key" of the students' notebooks and their success in mathematics?

3- Is there a meaningful relationship between the formal and contextual state points according to the "Notebook Point Key" of the students' notebooks?

\section{Method}

The design, work group, data collection devices, statistical methods, and techniques used in analyzing the data are explained in this part.

\subsection{The Design of the Study}

In this study, a complex method has been used, in which quantitative and qualitative techniques are combined. First, the qualitative data have been collected and analyzed, and then quantitative data gave been collected and analyzed to find 
the relationship between the points given for the students' notebooks according to the "Notebook Point Key" and the mathematical success of the students. This complex method is called "exploratory design." The reason for the use of this design is the need for the data collected with the quantitative method to be supported by qualitative method. It is also used to verify or expand the qualitative data with quantitative data (Fraenkel \& Wallen, 2006).

The quantitative data of the notebooks were collected and assessed to find the answers to the sub-problems that were determined in the first stage of the study. In the second stage, the relationship between the results of these assessments and the mathematical success points is revealed.

In the qualitative part of the study, the document examination method has been used. Each document (notebook) has been analyzed in terms of contents according to the "Notebook Point Key" developed by the researcher, and the data were gathered around certain concepts and themes and then made available for the readers to understand (Yıldırım \& Şimşek, 2008). For this purpose, contextual analysis of these notebooks has been performed under two categories as formal and contextual properties.

In the quantitative part of the study, the purpose was to state the existing situation and describe it as it is. For this purpose, the survey method was used. Moreover, since this study aims to determine the change between two variables and/or their degree, the correlational research method has been used (Fraenkel \& Wallen, 2006). The correlational research method has been used in examining the relationship between the contextual points of the students' notebooks and their mathematical success.

\subsection{Sample}

The purposive sampling method was used as the sampling method (Fraenkel \& Wallen, 2006). In this method, 228 students who were attending state secondary schools in 3 different cities have been chosen as the sampling item. The reason for the students having been chosen from among the second stage of primary education is that students at this level are accepted as having a certain amount of mathematical interest, in terms of skills and information. The distribution of the students in terms of classes is given in Table 1.

\subsection{Collection of Qualitative Data}

In the qualitative part of the study there are the data obtained from the examination of the students' notebooks in math classes. These data have been obtained by analyzing the data by means of content analysis. The content analysis has been performed with the "Notebook Point Key," which includes concepts and themes developed by the researcher (Appendix 2). During the development stage of this key, three mathematics teachers and two specialists who worked in state secondary schools have been contacted. They were interviewed using the form developed by the researcher (Appendix 1). The purpose of this interview was to understand their points of view on the subject (Patton, 1987). By doing so, the aim was to understand their experiences, attitudes, thoughts, intentions, comments, and mental perceptions (Yıldırım \& Şimşek, 2008). Moreover, the content validity of this key has been ensured with three other specialists.

The measurement tool consists of 18 items, which include formal and contextual dimensions. Formal items include notebook order, correct drawings of the figures, legibility of the writing, a spell check of the writing, information on the dates of the classes, missing points in the notes of the classes, writing the information from the board to the notebook, and taking extra notes. Contextual items include missing points in the questions and answers, taking notes on newly-encountered topics, figures being accurate to the properties, summarizing subjects, making self-directions on the topics, and using abbreviations. Notebooks have been assessed with values between 0-2. " 0 " means that the relevant property of the notebook is missing; " 1 " means the relevant property exists, but only partially; " 2 " means that the relevant property has been met sufficiently. To ensure the validity of the measurement tool, relevant specialist viewpoints about the draft form have been obtained.

After the content validity of the "Notebook Point Key," which assessed the students' notebooks in terms of formal and contextual properties, had been ensured, this key was reshaped according to the suggestions of the specialists, and applied in a study in which 53 students from a secondary state school participated, in order to ensure its reliability. After the pilot application, the KR-20 reliability coefficient has been calculated as .73 to find the reliability of the measurements.

\subsection{Collection of Quantitative Data}

The success marks of the students in math classes in the fall season of the academic year 2013-2014 have been calculated after the examinations and performance assessments. These success marks are grades that have counterparts in the 5-grade system. The marks in 5-grade system are as follows: 0-24 equals "0", 25-44 equals "1", 45-54 equals "2", 55-69 equals " 3 ", 70-84 equals " 4 ", and 85-100 equals " 5 ". The distribution of the students' grades is given in Table 1. 
Table 1. Distribution of success marks of the students in mathematics

\begin{tabular}{|c|c|c|c|c|c|c|c|c|c|c|}
\hline \multicolumn{11}{|c|}{ Grade Level } \\
\hline \multirow[t]{2}{*}{ Success marks } & \multicolumn{2}{|c|}{5.} & \multicolumn{2}{|c|}{6.} & \multicolumn{2}{|c|}{7.} & \multicolumn{2}{|c|}{8.} & \multicolumn{2}{|c|}{ Total } \\
\hline & $\%$ & $\mathrm{n}$ & $\%$ & $\mathrm{n}$ & $\%$ & $\mathrm{n}$ & $\%$ & $\mathrm{n}$ & $\%$ & $\mathrm{n}$ \\
\hline $1(25-44)$ & 4.08 & 2 & 18.75 & 18 & 18.18 & 8 & 33.33 & 13 & 17.98 & 41 \\
\hline $2(45-54)$ & 12.24 & 6 & 15.63 & 15 & 11.36 & 5 & 17.95 & 7 & 14.47 & 33 \\
\hline $3(55-69)$ & 16.33 & 8 & 27.08 & 26 & 25 & 11 & 17.95 & 7 & 22.81 & 52 \\
\hline $4(70-84)$ & 32.65 & 16 & 18.75 & 18 & 29.55 & 13 & 15.38 & 6 & 23.25 & 53 \\
\hline $5(85-100)$ & 34.69 & 17 & 19.79 & 19 & 15.91 & 7 & 15.38 & 6 & 21.49 & 49 \\
\hline Total & 100 & 49 & 100 & 96 & 100 & 44 & 100 & 39 & 100 & 228 \\
\hline
\end{tabular}

As we can see from Table 1, 49 students out of the 228 students who participated in the study are 5th Graders, 96 of them are 6th Graders, 44 of them are 7th Graders, and 39 of them are 8th Graders. When the mathematical success of these students is considered, it has been observed that 41 students received a 1,33 students received a 2, 52 students received a 3, 53 students received a 4, and 49 students received a 5 . Both successful and unsuccessful students in mathematics classes were included in the study. The classifications were made by the researcher, with the support of the specialists, as follows: "1" and " 2 " were considered unsuccessful, " 3 " was considered medium-successful, "4" and " 5 " were considered successful. Therefore, the data obtained from 176 students have been included in the study (not included medium-successful).

\subsection{Data Analysis}

The information obtained for the quantitative data of the study was processed on the computer after they were recorded and the statistical analyses have been performed. The analysis of the qualitative data has been performed using the content analysis method. The correlation statistics was performed in terms of the mathematical success marks and notebook assessment points. Moreover, the reliability formula developed by Miles and Huberman (1994) was used for the inter-rater reliability. Two specialists assessed the notebooks and determined the "Consensus" and "Dissidence" items. In order to verify the reliability of the coding performed by the researcher, the reliability value must be $70 \%$ or above (Yıldırım \& Şimşek. 2008). After the calculations, the value was found to be $78 \%$ and the study has been accepted as being reliable.

Reliability $=[($ Consensus $) /($ Consensus $)+($ Dissidence $)]$ x 100

\section{Results}

In this part of the study, the findings of the data obtained during the study are given. These findings are given after they have been put in order of the sub-problems of the study.

\subsection{The Relationship between the Formal States of the Students' Notebooks and Their Success Rates}

The data on the relationship between the points obtained from the "Notebook Point Key" system given to the students' notebooks, in terms of the formal states of the notebooks and the success of the students, are given in Table 2.

Table 2. The relationship between the success and the formal properties of the students' notebooks

\begin{tabular}{llll}
\hline & & Formal & Success \\
\hline \multirow{3}{*}{ Formal } & Pearson Correlation & 1.000 & $.304^{*}$ \\
& Sig. (2-tailed) & - & .124 \\
& N & 176 & 176 \\
Success & Pearson Correlation & $.304^{*}$ & 1.000 \\
& Sig. (2-tailed) & .124 & - \\
& $\mathrm{N}$ & 176 & 176 \\
\hline
\end{tabular}

${ }^{*}$ Correlation is significant at the 0.05 level (2-tailed)

When Table 2 is considered, it becomes clear that there is no meaningful relationship between the success of the students and the formal properties of their notebooks $(\mathrm{r}=0.304, \mathrm{p}<.05)$. In this context, it can be suggested that, as mathematical success increases, the formal properties of the notebooks do not change. However, it has also been found that the formal property points of the notebooks of the students who are successful are higher than those who are unsuccessful. In this context, it has been suggested that success is partly influenced by note-taking.

The views of the notebooks of some students who took notes during math classes are given below. 


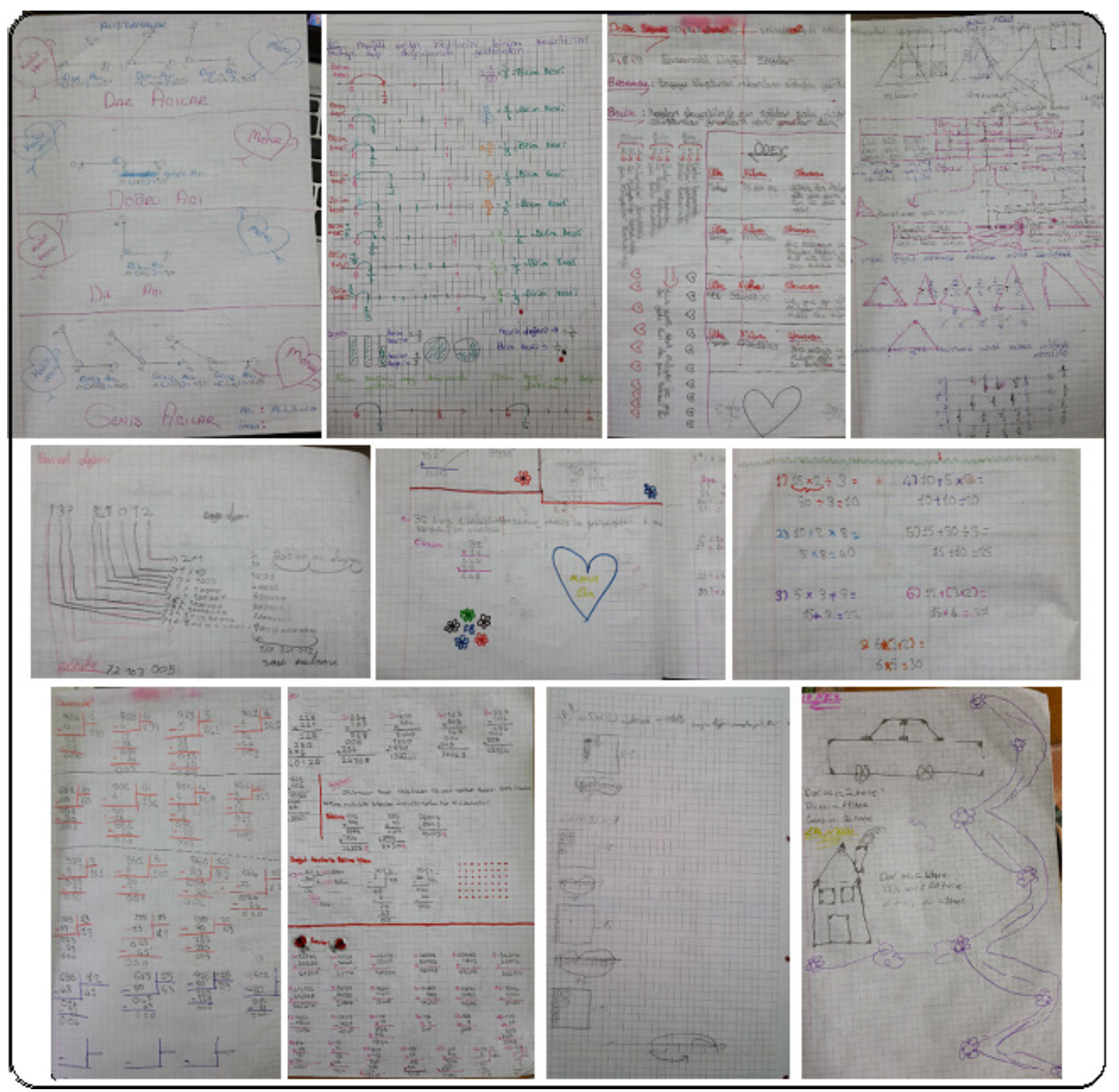

Figure 1. Sample views of the notebooks of the students in mathematics classes

It is shown in Figure 1 that some formal examples belonging to the content analysis of the notebooks show that some students were taking notes which were not related to the course, using colorful pens, which are not contextual, drawing general patterns, etc. It has been observed that unsuccessful students fail to pay attention to the course or the teacher in the same way that successful students do.

\subsection{The Relationship between the Contextual State of the Students' Notebooks and Their Success Rates}

Table 3 gives the information showing the relationship between the "success" classification and the points given for the students' notebooks according to the "Notebook Point Key," in terms of contextual properties.

Table 3. The relationship between the contextual state of the students' notebooks and their success

\begin{tabular}{clrr}
\hline & & Contextual & Success \\
\hline \multirow{2}{*}{ Contextual } & Pearson Correlation & 1.000 & $.716^{*}$ \\
& Sig. (2-tailed) & - & .000 \\
& N & 176 & 176 \\
& Pearson Correlation & $.716^{*}$ & 1.000 \\
Success & Sig. (2-tailed) & .000 & - \\
& $\mathrm{N}$ & 176 & 176 \\
\hline
\end{tabular}

* Correlation is significant at the 0.05 level (2-tailed)

When Table 3 is examined, it becomes clear that there is a meaningful relationship between mathematical success and 
the contextual properties of the students' notebooks $(\mathrm{r}=0.716, \mathrm{p}<0.05)$. In this context, it has been observed that the contextual properties of the students' notebooks are related to their success. When the students' notebooks are examined, it is believed that students who are unsuccessful in mathematics do not pay attention to the contextual properties, and this affects their success. For this reason, it has become obvious that the activity of writing is important in that it directly affects success, and meaningful and contextual writing is also important in reaching success in mathematics.

Views of contextual properties of some of the students' notebooks in math classes are given below.

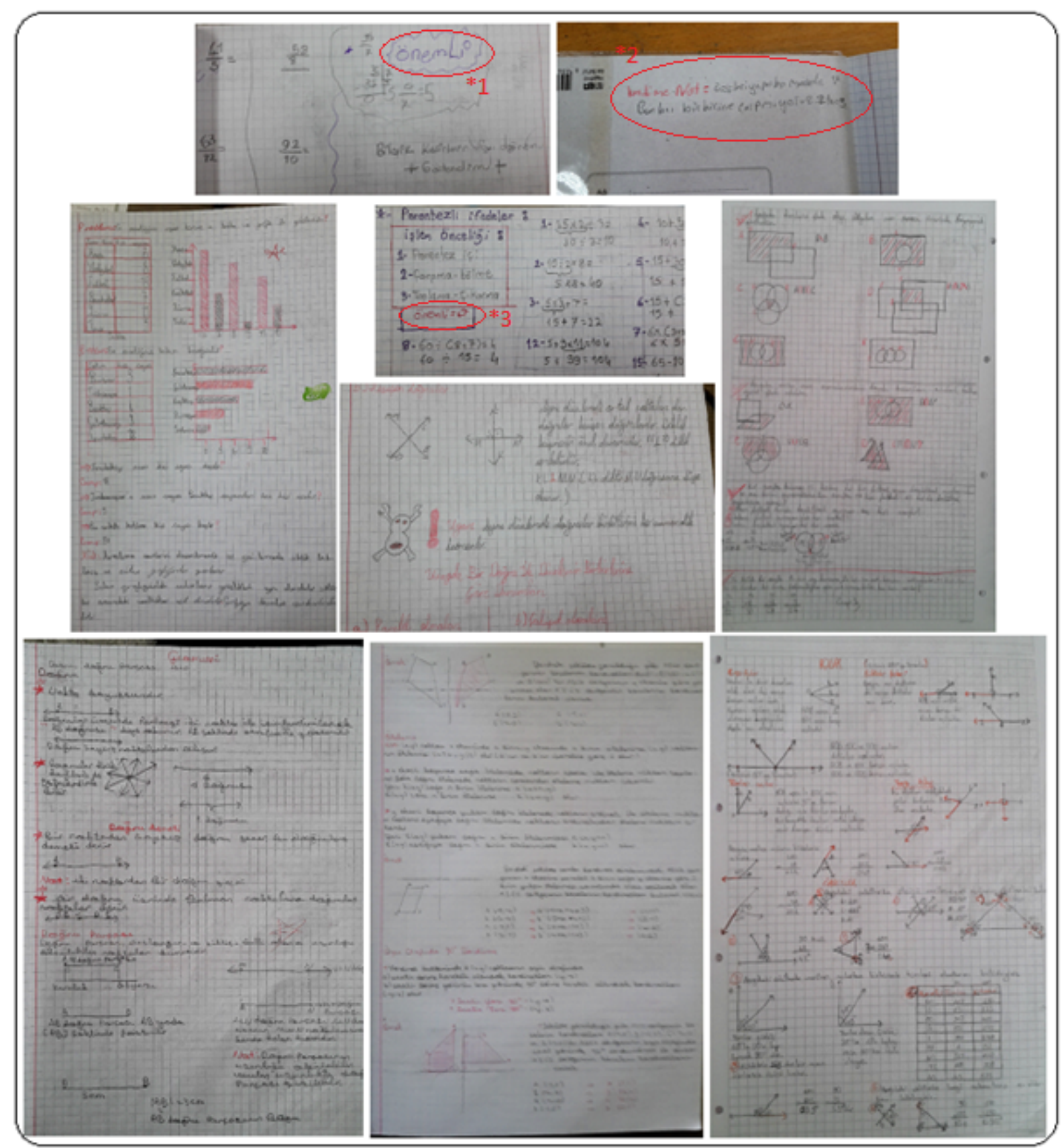

*1, *3 “Important," *2 "Note for me," students' own notes.

Figure 2. Sample views of the notebooks of the students in mathematics classes.

Figure 2 shows contextual examples from the notebooks of some students. The amount of contextual note-taking by successful math students is much greater than unsuccessful students. Moreover, it is observed that the former get some inferences and note these inferences with messages to themselves, such as "important," "note for me," etc. 


\subsection{The Formal and Contextual Properties of the Students' Notebooks}

Table 4 shows the information on the relationship between formal properties and contextual properties of the students' notes and the points according to the "Notebook Point Key."

Table 4. The relationship between the formal and contextual states of the students' notebooks

\begin{tabular}{clrr}
\hline & & Formal & Contextual \\
\hline \multirow{2}{*}{ Formal } & Pearson Correlation & 1.000 & $.488^{*}$ \\
& Sig. (2-tailed) & - & .055 \\
& N & 176 & 176 \\
& Pearson Correlation & $.488^{*}$ & 1,000 \\
Contextual & Sig. (2-tailed) & .055 & - \\
& N & 176 & 176 \\
\hline
\end{tabular}

* Correlation is significant at the 0.05 level (2-tailed)

When Table 4 is examined, it is observed that there is not a meaningful relationship between the formal and contextual properties of the students' notebooks. This shows that the formal and contextual properties are different from each other.

\section{Discussion and Conclusions}

In this study, the success of the students in math classes and their notebooks are compared in terms of formal and contextual states. It has been observed empirically that the relationship between the success of the students and their writing status, i.e. their note-taking status, can be positive.

When the students' notebooks were examined, it became obvious that they also took notes that were not relevant to the subject. This situation shows the interest of the students in the lesson and affects their success. Their use of colored pens during note-taking attracts attention, not in terms of contextual shape, but in terms of formal property. The students have used colored pens while note-taking on important issues and they have succeeded in mathematics as a result. Those who did not take notes were unsuccessful. However, since it is believed that the attention of students on formal properties will improve individual skills such as self-organizing, it is also believed that formal properties are important as well (Graham \& Harris, 2000). The formal states of the successful students' notebooks are more positive than of those who are unsuccessful.

It has also become obvious that students' using different forms and expressions while taking notes has an effect on success. One of the reasons for this is that those students make deductions and then take notes when they feel it is important. The neatness of the students is the same both in successful and unsuccessful students, but slightly better in successful students. Successful students take additional notes from different sources and do not take notes verbatim from the teachers during the lessons. In light of these observations, it has been suggested that writing activities are important in examining the problem solving processes of the students (Pugalee, 2001). This is because writing activities are among many other methods in examining mathematical problem solving processes (Taylor \& McDonald, 2007). It has been observed in the notebooks that unsuccessful students have missing points in their notes during problem solving processes. This situation affects the success of the students directly.

When the correctness of the drawings and figures were considered, it became obvious that unsuccessful students could partially draw the figures correctly, but could not reflect the properties of them. It also became clear that successful students could define the properties of the figures better in terms of context. It was observed in both groups of students that neither group had written the date of the subjects on their notebooks. This situation is thought to be useful in studying past subjects and in remembering those subjects. It was observed that the legibility of the writing of the successful students was better, and positive, when compared to that of the unsuccessful students. While Camila (1998) states that writing has no effect on success, it is seen that taking contextual notes (writing) is, in fact, related to success. What's more, Dilbartolo (2000) indicates that students have positive attitudes towards mathematics thanks to writing.

It has become obvious that, among the factors affecting the mathematical success, writing is also important and should be developed with studies directed toward it (Rothstein et al., 2007). It is clear that writing has an important role in teaching mathematics (NCTM, 1989). Moreover, seminars on topics such as "How to take good notes in math class" should be organized at the beginning of the academic year/term. This will increase the success of the students. It can be possible to evaluate success of students and to examine notes of students formally according to topics of the notes by applying different practices of writing, which topics students tending can be identified at the end, as stated by Burns (2004).

\section{References}

Albert, L. R. (2000). Outside in-inside out: Seventh grade students' mathematical thought processes. Educational Studies in Mathematics, 41, 109-141. http://dx.doi.org/10.1023/A:1003860225392 
Atasoy, E. (2005). Matematik ögretiminde yazmanın kullanılması [Use of writing in teaching mathematics]. (Master dissertation). Karadeniz Technical University, Trabzon.

Atasoy, E. (2012). Yazma uygulamalart ile destekli matematik derslerinin öğrenme ve ögretme boyutlarından incelenmesi [The examination of writing based activities in athematics from the perspectives of learning and teaching]. (Unpublished doctoral dissertation). Karadeniz Technical University, Trabzon.

Atasoy, E., Baki, A., \& Atasoy, Ş. (2005). A study on the use of writing in mathematics education. XIV. National Congress of Education Science in Pamukkale University Education Faculty, 28-30, Denizli.

Bell, E. S., \& Bell, R. N. (1985). Writing and problem solving: Arguments in favour of synthesis. School Science and Mathematics, 85(3), 210-221.

Browne, A. (1999). Teaching writing at key stage 1 and before. Cheltenham: Stanley Thornes.

Burns, M. (2004). Writing in math. Educational Leadership, 62(2), 30-33. http://www-tc.pbs.org/teacherline/courses/rdla230/docs/session_1_burns.pdf

Camilla, R. S. (1998). Urban algebra I students' perceptions of journal writing and effect on achievement with integers and students' attitudes toward mathematics. (Doctoral dissertion), The University of Mississippi.

Connelly, M. (2005). Writing in math. http://www.teachersnetwork.org/tnli/research/achieve/connelly.pdf

Countryman, J. (1992). Writing to Learn Mathematics: Strategies that Work. Portsmouth, N.H.: Heinemann.

Cakmak, E. (2013). The effect of teaching argumentative writing on teacher candidates' argumentative writing skills. Journal of Theory and Practice in Education, 9(4), 379-389.

Demircioğlu, H., Argün, Z., \& Bulut, S. (2010). The views of preservice secondary mathematics teachers about use of "Writing" technique. Journal of Social Science Cumhuriyet University, 34(2), 40-46.

Dibartolo, M.T. (2000). Writing opportunities as a teaching / Learning tool in a college mathematics course. (Doctoral dissertation). Columbia University.

Freitag, M. (2004). Reading and writing in the mathematics classroom, The Mathematics Educator, 8(1), 24-29.

Fraenkel, J. R., \& Wallen, N. E. (2006). How to design and evaluate research in education. Newyork: McGraw-Hill.

Frenkel, J. J. (2004). Writing use and its effectiveness on high school students' mathematics performance, Degree of Master, University of Wisconsin-Oshkosh.

http://www.uwosh.edu/coehs/departments/curriculum-instruction-epartment/documents/Frenkel2004Fall.pdf

Graham, S., \& Harris, K. R. (2000). The role of self regulation and transciption skills in writing and writing development. Educational Psychologist, 35(1), 3-12. http://dx.doi.org/10.1207/S15326985EP3501_2

Güneş, F. (2013). Türkçe öğretimi-Yaklaşımlar ve modeller [Turkish teaching - Approaches and models]. Ankara: Pegem Academy Publishing.

Ishii, D. K. (2003). First-time teacher-researchers use writing in middle school mathematics instruction. The Mathematics Educator, 13(2), 38-46.

Kobayashi, K. (2005). What limits the encoding effect of note-taking? A meta-analytic examination. Contemporary Educational Psychology, 30(2), 242-262. http://dx.doi.org/10.1016/j.cedpsych.2004.10.001

Lahtinen, V., Lonka, K., \& Lindblom-Ylanne, S. (1997). Spontaneous study strategies and the quality of knowledge construction. British Journal of Educational Psychology, 67, 13-24. http://dx.doi.org/10.1111/j.2044-8279.1997.tb01223.x

Jurdak, M., \& Zein, R. A. (1998). The effect of journal writing on achievement in and attitudes toward mathematics. School Science and Mathematics, 98(8), 412-419. http://dx.doi.org/10.1111/j.1949-8594.1998.tb17433.x

Miles, M., \& Huberman, M. (1994). Qualitative data analysis (2nd ed.). USA: Sage Publications.

Ministry of National Education (2009). Elemantary turkish courses curriculum and guides (1-5. Grades). Ankara: Publications Directorate of State Books.

Ministry of National Education (2012). Authoring and writing skills course curriculum. http://ttkb.meb.gov.tr/www/ogretim-programlari/icerik/72

National Council of Teachers of Mathematics (1989). Curriculum and evaluation standards for school mathematics. Reston: Author.

O'Connell, S. (2007). Introduction to communication grades 3-5. The math process standarts series. Portsmouth, NH: 
Heinemann.

Özgen, K. (2013). Mathematical connection skill in the context of problem solving: The case of pre-service teachers. NWSA-Education Sciences, 8(3), 323-345.

Patton, M. Q. (1987). How to use qualitative methods in evaluation. Newbury Park, CA: Sage.

Phillips, E., \& Crespo, S. (1996). Developing Written Communication in Mathematics Through Math Penpal Letters. For the Learning of Mathematics, 16(1). 15-22. FLM Publishing Association, Vancouver, British Columbia, Canada.

Powell, A. B. (1997). Writing in Mathematics, Clearing House, 71(1).

Pugalee, D. K. (2001). Writing, mathematics, and metacognition: Looking for connections thorugh students' work in mathematical problem solving. School Science and Mathematics, 101(5), $236-245$. http://dx.doi.org/10.1111/j.1949-8594.2001.tb18026.x

Pugalee, D. K. (2004). Acomparision of verbal and written descriptions of students' problem solving processes, Educational Studies in Mathematics, 55, 27-47. http://dx.doi.org/10.1023/B:EDUC.0000017666.11367.c7

Rice, C. (2004). How does using writing to teach math affect student math understanding? An exploration of metacognitive awareness in the mathematics classroom. Action Research Paper EDUG 522: Action Research For Teachers III. Spring. http://academic.georgefox.edu/ kcarr/mat/docs/studentwork/Action\%20Research.doc

Rothstein, A., Rothstein, E., \& Lauber, G. (2007). Write for mathematics. California: Corwin Press, Thousand Oaks.

Shield, M., \& Galbraith, P. (1998). The analysis of student expository writing in mathematics. Educational Studies in Mathematics, 36(1), 29-52. http://dx.doi.org/10.1023/A:1003109819256

Song, S. H. (1997). Writing to understand in the math classroom. Tacoma: Pacific Lutheran University.

Taylor, J. A., \& McDonald, C. (2007). Writing in groups as a tool for non-routine problem solving in first year university mathematices. International Journal of Mathematics Education in Science and Technology, 38(5), 639-655. http://dx.doi.org/10.1080/00207390701359396

Yıldırım, A., \& Şimşek, H. (2005). Qualitative research methods in social sciences (5. Edition). Ankara: Seckin Publishing.

Yore, L. D., Pimm, D., \& Tuan, H. L. (2007). The literacy component of mathematical and scientific literacy. International Journal of Science and Mathematics Education, 5(4), 559-589. http://dx.doi.org/10.1007/s10763-007-9089-4

\section{Appendix. 1}

\section{The Interview Form}

1 - Do you examine the notebooks of the students?

2- What criteria do you consider during your examination of the notebooks?

3- What do you think are the characteristics of a good notebook?

4- Do you think that a good writing skill affects the mathematical success?

5- In your opinion, are there any differences between the note-taking of the successful students and unsuccessful students?

N.B.: If you have something different to say about writing, note-taking and other similar activities that affect mathematical success, please state! 
Appendix. 2

\begin{tabular}{|c|c|c|c|c|c|}
\hline No & Items & $\mathbf{0}$ & 1 & 2 & State \\
\hline 1 & Neatness of the notebook (cleanness/wear \& tear) & & & & $\mathbf{F}$ \\
\hline 2 & Writing the questions and their answers in problem solving accurately & & & & $\mathbf{C}$ \\
\hline 3 & Taking notes about newly-encountered concepts & & & & $\mathbf{C}$ \\
\hline 4 & Drawing the figures accurately & & & & $\mathbf{F}$ \\
\hline 5 & Paying attention to the properties of the figures & & & & $\dot{\mathbf{I}}$ \\
\hline 6 & The legibleness of the writing & & & & $\mathbf{F}$ \\
\hline 7 & Paying attention to spell-check & & & & $\mathbf{F}$ \\
\hline 8 & Summarizing the subjects & & & & $\mathbf{C}$ \\
\hline 9 & Using abbreviations & & & & $\mathbf{C}$ \\
\hline 10 & The errors being correctable / making corrections on them & & & & $\mathbf{C}$ \\
\hline 11 & Does each lesson have a date written? & & & & $\mathbf{F}$ \\
\hline 12 & Are there notes belonging to all subjects studied? & & & & $\mathbf{F}$ \\
\hline 13 & Does the student write only the notes on the board during note-taking? & & & & $\mathbf{F}$ \\
\hline 14 & Taking additional notes about the important points & & & & $\mathbf{C}$ \\
\hline 15 & Underlining the important points of a subject & & & & $\mathbf{C}$ \\
\hline 16 & Marking the important points of a subject with colored pens & & & & $\mathbf{C}$ \\
\hline 17 & Defining important points of a subject with specific symbols. & & & & $\mathbf{C}$ \\
\hline 18 & $\begin{array}{l}\text { Directing students with clues, key words or sentences, such as "This is } \\
\text { important!" etc. }\end{array}$ & & & & $\mathbf{C}$ \\
\hline 19 & Note-taking outside the classroom etc. & & & & $\mathbf{C}$ \\
\hline \multicolumn{5}{|c|}{ Total } & \\
\hline
\end{tabular}

$* \mathrm{~F}=$ Formal properties, $\mathrm{C}=$ Contextual properties

This work is licensed under a Creative Commons Attribution 3.0 License. 